\title{
An observation of two oceanic salp swarms in the Tasman Sea: Thetys vagina and Cyclosalpa affinis
}

\author{
Natasha Henschke $e^{1,2,3^{*}}$, Jason D. Everett ${ }^{1,2,3}$ and lain M. Suthers ${ }^{1,2,3}$
}

\begin{abstract}
Background: Large oceanic salps are rarely encountered. The highest recorded biomasses of the salps Thetys vagina (852 $\mathrm{g} \mathrm{WW} \mathrm{m}^{-3}$ ) and Cyclosalpa affinis (1149 $\mathrm{g} \mathrm{WW} \mathrm{m}^{-3}$ ) were observed in the Tasman Sea during January 2009.

Results: Due to their fast sinking rates the carcasses and faecal pellets of these and other large salps play a significant role in carbon transport to the seafloor. We calculated that faecal pellets from these swarms could have contributed up to $67 \%$ of the mean organic daily carbon flux in the area. This suggests that the flux of carbon from salp swarms are not accurately captured in current estimates.
\end{abstract}

Conclusion: This study contributes information on salp abundance and biomass to a relatively understudied field, improving estimates for biogeochemical cycles.

\section{Background}

The role of gelatinous zooplankton, such as salps, pyrosomes and cnidarians, in ocean food webs and biogeochemical cycling has garnered increased attention in recent years (Lebrato et al., 2011; Henschke et al., 2013; Lebrato et al., 2013; Smith et al. 2014). Salps (Phylum: Thaliacea, Order Salpidae) in particular, are significant contributors to oceanic carbon flux. They have the highest per-individual filtration rates of all marine zooplankton filter feeders (Alldredge and Madin, 1982) consuming particles across three orders of magnitude $(1 \mu \mathrm{m}$ up to $1 \mathrm{~mm}$ in size; Vargas and Madin, 2004; Sutherland et al., 2010) using a fine mucous net that is continuously secreted and fed toward the oesophagus. This efficient feeding mechanism and their alternating sexual and asexual life-cycle results in fast individual (up to $21 \%$ in length $\mathrm{h}^{-1}$; Heron, 1972a) and population (up to $2.5 \mathrm{~d}^{-1}$; Heron, 1972b; Henschke et al., 2015) growth rates. As a result, salps form large swarms that often reach abundances greater than

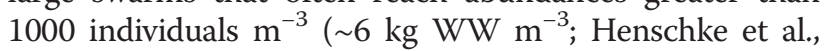
2014) and persist for up to 6 months (Smith et al. 2014). When salps occur in high abundances, their fast-sinking faecal pellets (Bruland and Silver, 1981) and carcasses

\footnotetext{
* Correspondence: n.henschke@unsw.edu.au

${ }^{1}$ Evolution and Ecology Research Centre, University of New South Wales,

Sydney, NSW 2052, Australia

${ }^{2}$ Sydney Institute of Marine Science, Building 22, Chowder Bay Road,

Mosman, NSW 2088, Australia

Full list of author information is available at the end of the article
}

(Henschke et al., 2013) can increase the carbon flux in an area up to ten-fold the daily average (Fischer et al., 1988) for a sustained period of time (Smith et al. 2014).

Due to their regular occurrence (Henschke et al., 2014) and coastal dominance (Henschke et al 2011), smaller salps such as Thalia democratica are studied with greater frequency. Although these smaller salps contribute significantly to biogeochemical cycling with fast growth rates (Heron, 1972a) and faecal pellets, carcasses of these smaller salps rarely sink as they are neutrally buoyant (Tsukamoto et al., 2009). The carcasses of larger salps however, sink rapidly and have the potential to reach the sea floor in less than 2 days (Henschke et al., 2013; Lebrato et al., 2013). Due to the combined input from both faecal pellets and carcasses, swarms of larger salps are thought to play a greater role in carbon export (Smith et al. 2014). Of significance however, is that very little is known about the distribution and abundance of larger salps as they are oceanic and rarely encountered. The aim of this study is to document swarm observations from the Tasman Sea of two large salps: Thetys vagina and Cyclosalpa affinis and compare these biomasses to previous observations.

Thetys vagina is often observed opportunistically as a single individual and little is known about their ecology (Nakamura and Yount, 1958; McAlice, 1986; Sims, 1996; Stone and Steinberg, 2014). Large biomasses (900 t WW $\mathrm{km}^{-3}$ ) of $T$. vagina have been observed in the Japan Sea (Iguchi and Kidokoro, 2006) and Tasman Sea (Thompson, 
1948; Henschke et al., 2013). Although T. vagina has been found across a wide temperature $\left(7-20{ }^{\circ} \mathrm{C}\right.$ ) and salinity (33.9-35.6) range (Thompson, 1948; Iguchi and Kidokoro, 2006; Henschke et al., 2013), there appears to be no seasonality to $T$. vagina swarms (Henschke et al 2013). In the Japan Sea and Tasman Sea, higher T. vagina biomass occurred in areas of higher chlorophyll $a$ (Iguchi and Kidokoro, 2006; Henschke et al., 2013). As seamounts have been found to promote localised upwelling (Boehlert and Genin, 1987; Suthers, 1996), this is one factor that may have encouraged the $T$. vagina population to aggregate around Gascoyne Seamount in this report.

Although the ecology of Cyclosalpa affinis is well studied (e.g. Madin, 1974; Madin et al., 1981; Vargas and Madin, 2004), their distribution is not well known. Unlike T. vagina, the relationship between upwelling events and C. affinis populations is unknown. Long-term studies have found that $C$. affinis generally occurs in low numbers $\left(<30 \mathrm{~g} \mathrm{WW} \mathrm{m}^{-3}\right)$ and has been characterised as a coolphase species, occurring after intrusions of cooler high latitude water (Lavaniegos and Ohman, 2003). However, C. affinis has also been found in the subtropical Tasman Sea $\left(32.8^{\circ} \mathrm{S}\right.$ and $\left.32.57^{\circ} \mathrm{S}\right)$ and the warmer parts of the Indian, Pacific and Atlantic oceans (Thompson, 1948) suggesting that its temperature tolerance may be quite broad.

\section{Methods}

Salp samples were collected onboard the R.V. Southern Surveyor in the austral summer (25-29 January 2009) in the western Tasman Sea (Fig. 1). Sampling stations were located at Gascoyne Seamount $(n=5)$ and on the Challenger Plateau $(n=1)$. Gascoyne Seamount is part of the Tasmantid Seamount Chain in the Tasman Sea, and rises to $93 \mathrm{~m}$ below the surface from a bottom depth of $4000 \mathrm{~m}$ (Quilty, 1993). The Challenger Plateau is a large submarine plateau west of New Zealand, with depths varying from 500 to $1500 \mathrm{~m}$, and is considered to be a region of low pelagic productivity (Wood, 1991).

At each sampling station a Seabird SBE911-plus Conductivity-Temperature-Depth (CTD) recorder equipped with an AquaTracker Mk3 fluorometer (Chelsea, UK) was used to record salinity, temperature, and fluorescence, respectively. Salps were sampled at the surface with a neuston net $(0.75 \mathrm{~m} \times 0.75 \mathrm{~m}, 500 \mu \mathrm{m}$ mesh; $n=2)$ and from 0 to $40 \mathrm{~m}$ using a rectangular mid-water trawl (RMT; $1 \mathrm{~m} \times 1 \mathrm{~m}, 1 \mathrm{~mm}$ mesh, double-oblique tows; $n=1)$. The neuston net was towed for $5 \mathrm{~min}$, and the RMT for $30 \mathrm{~min}$, both at $1.5 \mathrm{~m} \mathrm{~s}^{-1}$. All tows were undertaken at night (2100-0200 h). Immediately after sampling, zooplankton were preserved in $5 \%$ formaldehye solution. Salps were identified to species and total length and wet
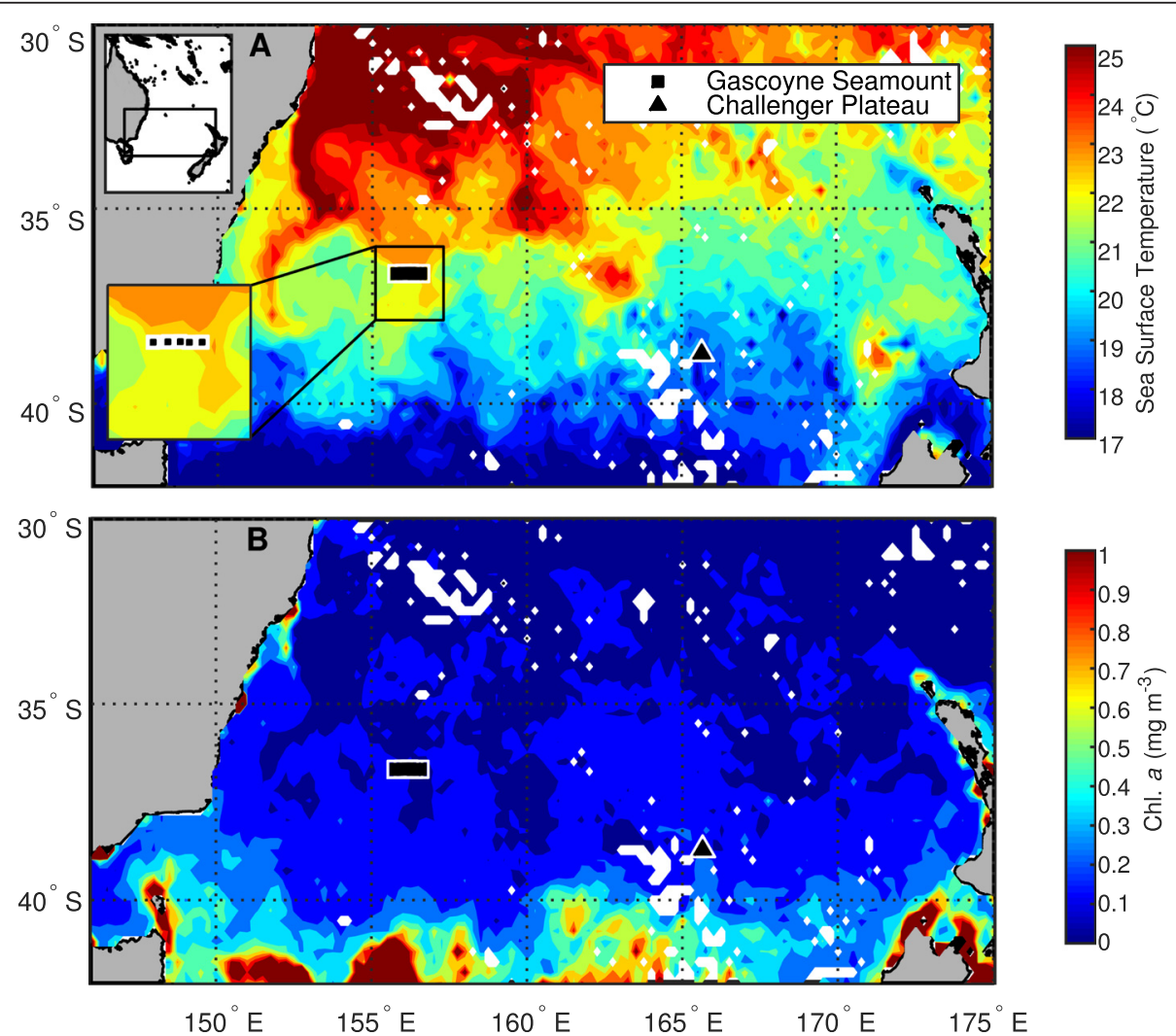

Fig. 1 Location plot showing sampling locations in the Tasman Sea. Overlaid is satellite derived a) sea surface temperature and $\mathbf{b}$ ) chlorophyll $a$ Sampling stations on Gascoyne Seamount are represented by squares $(n=5)$ and Challenger Plateau is represented by triangles ( $n=1)$ 
weight was measured for each individual. Due to salps being damaged in the RMT net, total length of salps from the RMT samples could not be measured. Carbon calculations were based on carbon-length relationships previously established for T. vagina (Henschke et al., 2013) and C. affinis (Madin et al., 1981). Pearson correlations were undertaken to determine if there were any relationships between salp biomass and location to the seamount.

\section{Results and discussion}

The Gascoyne Seamount transect extended for $38 \mathrm{~km}$ crossing west-east over the seamount. At the time of sampling, sea surface temperature at Gascoyne Seamount was $\sim 22{ }^{\circ} \mathrm{C}$ compared to Challenger Plateau which was cooler $\left(\sim 19{ }^{\circ} \mathrm{C}\right)$ and had higher chlorophyll a concentrations (Fig. 1). Thetys vagina was present at all Gascoyne Seamount stations $(n=5)$ but absent at Challenger Plateau $(n$ $=1$ ) where only Cyclosalpa affinis occured. Biomass of $T$. vagina did not significantly differ with distance to the seamount (Pearson correlation, $\mathrm{R}=-0.36, p=0.55$ ).

\section{Biomass and abundance}

At Gascoyne Seamount, mean $( \pm \mathrm{SE})$ surface biomass of Thetys vagina was $444.9 \pm 249.8 \mathrm{~g}$ WW $\mathrm{m}^{-3}$ $\left(6.6 \mathrm{mg} \mathrm{C} \mathrm{m}^{-3}\right)$ and the mean $( \pm \mathrm{SE})$ oblique biomass was $851.7 \pm 280.6 \mathrm{~g} \mathrm{WW} \mathrm{m}^{-3}$ (12.7 $\mathrm{mg} \mathrm{C} \mathrm{m}^{-3}$; Fig. $\left.2 \mathrm{~d}\right)$. These values are higher than biomasses previously sampled in the Japan Sea (maximum of $0.9 \mathrm{~g} \mathrm{WW} \mathrm{m}^{-3}$; Iguchi and Kidokoro, 2006) and Tasman Sea (maximum of $0.7 \mathrm{~g}$ WW m ${ }^{-3}$; Henschke et al., 2013). At one station during sampling, the weight of high abundances of T. vagina tore the RMT net. Higher biomasses in the oblique tows (vs. neuston tows) suggest that $T$. vagina were more abundant deeper in the water column (Fig. 2d). Aggregation of salp biomass in the top $40 \mathrm{~m}$ is consistent with previous research that has found that $98 \%$ of $T$. vagina abundances occurred in the top $200 \mathrm{~m}$ during both day and night (Henschke et al., 2013). There is no known data on vertical migration by $T$. vagina and all samples in this study were undertaken only at night, but anecdotal observations from this cruise and previous cruises suggest they are not present in surface waters during the day.

Cyclosalpa affinis was only observed at the Challenger Plateau, with a surface biomass of $1148.6 \mathrm{~g} \mathrm{WW} \mathrm{m}^{-3}$ (4.3 $\mathrm{mg} \mathrm{C} \mathrm{m}^{-3}$ ) and oblique biomass of $2251.4 \mathrm{~g} \mathrm{WW} \mathrm{m}^{-3}$ (8.3 $\mathrm{mg} \mathrm{C} \mathrm{m}{ }^{-3}$; Fig. 2h). Compared to Gascoyne seamount, the water was cooler and less saline at the Challenger Plateau with a $100 \mathrm{~m}$ depth-integrated temperature of $15{ }^{\circ} \mathrm{C}$ compared to $19{ }^{\circ} \mathrm{C}$ (Fig. 2e,f). The fluorescence at Challenger Plateau was higher in the surface waters,

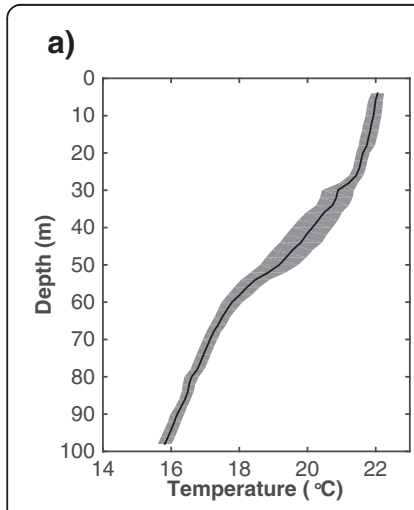

e)

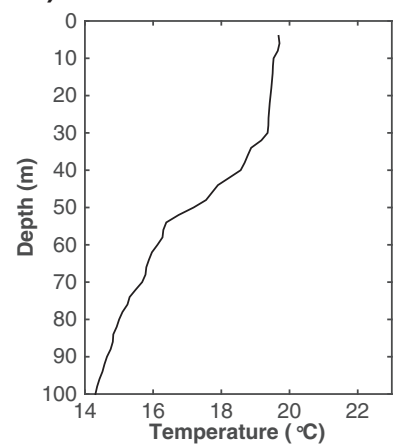

b)

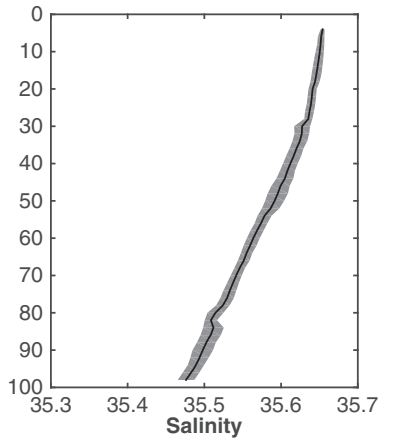

f)

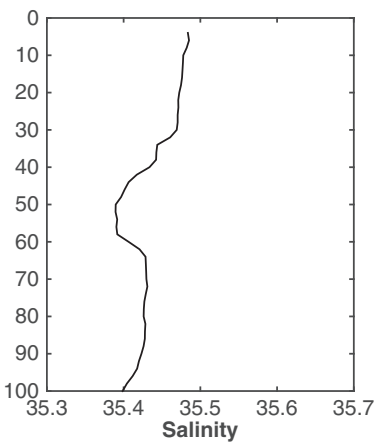

c)

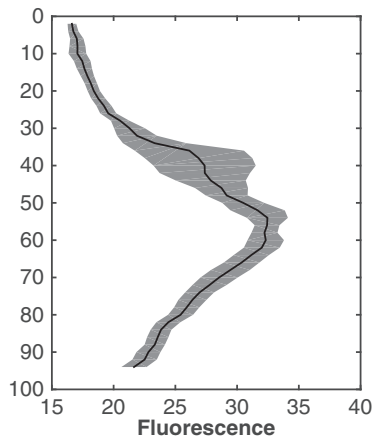

g)

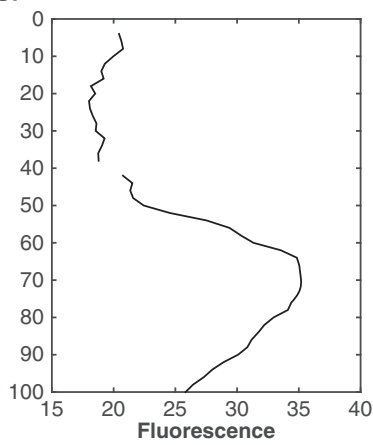

d)

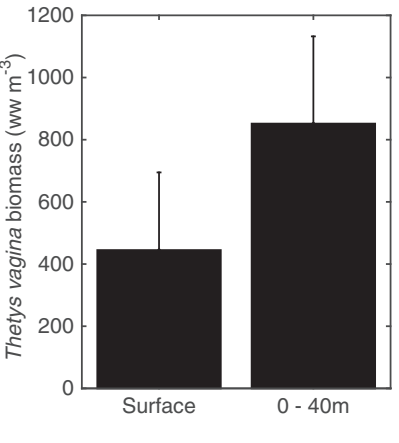

h)

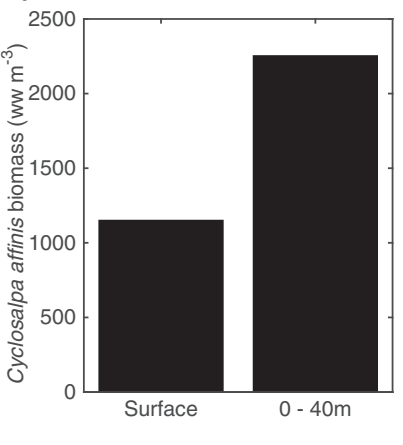

Fig. 2 Depth stratified temperature $(\mathbf{a}, \mathbf{e})$, salinity $(\mathbf{b}, \mathbf{f})$ and fluorescence $(\mathbf{c}, \mathbf{g})$ values for Gascoyne Seamount (top row) and Challenger Plateau (bottom row) sampling stations. Shaded values indicate standard error around the mean. Mean ( \pm SE) $\mathbf{d})$ Thetys vagina and $\mathbf{h}$ ) Cyclosalpa affinis biomass at the surface and oblique $(0-40 \mathrm{~m})$ depths are represented in the bar chart. As only one station was sampled at Challenger Plateau, standard errors around the mean could not be calculated for temperature, fluorescence or salp biomass 
but showed a similar sub-surface maximum at $60 \mathrm{~m}$ to Gascoyne Seamount (Fig. 2c,g). C. affinis is not believed to undergo diel-vertical migration (Madin et al., 1996) and to date this is the largest observed biomass of $C$. affinis population.

\section{Size structure}

Thetys vagina aggregates ranged from 21 to $135 \mathrm{~mm}$ in size (mean $=48 \mathrm{~mm}, n=179$ ), and solitaries ranged from 11 to $178 \mathrm{~mm}$ (mean $=27 \mathrm{~mm}, n=25$; Fig. 3a). Despite the large size range, the majority of aggregate and solitary individuals were small with respective modes of 39 and $19 \mathrm{~mm}$. Fully grown $T$. vagina individuals are reported to be up to $306 \mathrm{~mm}$ for solitary forms (Nakamura and Yount, 1958) and $190 \mathrm{~mm}$ for aggregate forms (Thompson 1948). It is unknown what size aggregate $T$. vagina embryos are when they are born, however, McAlice (1986) observed developing embryos between 10 and $15 \mathrm{~mm}$ inside a solitary individual. The abundance of small individuals $(<40 \mathrm{~mm})$ suggests that the T. vagina swarm observed at Gascoyne seamount had recently developed.

C. affinis aggregates ranged from 9 to $77 \mathrm{~mm}$ in length (mean $=37 \mathrm{~mm}, n=36$; Fig. 3b). Unlike T. vagina, there appears to be two distinct aggregate size classes in the C. affinis population with respective modes of $14(n=4)$ and $66 \mathrm{~mm}(n=3)$. Only 3 solitaries were measured and lengths ranged from 56 to $96 \mathrm{~mm}$ (mean $=74 \mathrm{~mm}$ ) with no developing buds observed. C. affinis aggregates reach a maximum size of $80 \mathrm{~mm}$ (Thompson, 1948), suggesting that the swarm has been developing for a while, and a cohort of solitary buds may have already been released from the larger aggregates.

\section{Potential carbon input}

Salps are significant contributors to oceanic carbon flux (Henschke et al., 2013; Smith et al. 2014). The defecation rate of Cyclosalpa affinis has been calculated at $9.9 \mu \mathrm{g} \mathrm{C}$ mg body $\mathrm{C} \mathrm{h}^{-1}$, and although no defecation rate has been calculated for Thetys vagina, we can assume an average defecation rate of $11.8 \mu \mathrm{g} \mathrm{C} \mathrm{mg} \mathrm{body} \mathrm{C} \mathrm{h}^{-1}$ based on a range of salp species (Madin and Deibel, 1998). Therefore, using the mean surface salp biomass from this study (and assuming a 1:1 conversion for $\mathrm{m}^{3}: \mathrm{m}^{2}$ ), $T$. vagina faecal pellets would have contributed $\sim 2 \mathrm{mg} \mathrm{C} \mathrm{m}{ }^{-2} \mathrm{~d}^{-1}$ at Gascoyne Seamount, and C. affinis would have contributed $\sim 1 \mathrm{mg}$ faecal carbon $\mathrm{m}^{-2} \mathrm{~d}^{-1}$ at the Challenger Plateau. These carbon flux values are likely to be an underestimation, as we have not considered population growth and the carbon input from carcasses. Considering the mean organic carbon flux in the area has been calculated as $4.5 \mathrm{mg} \mathrm{C} \mathrm{m}^{-2} \mathrm{~d}^{-1}$ (Kawahata and Ohta, 2000), it is likely that the contribution from salp swarms is not accurately captured in current estimates.

\section{Conclusion}

This study confirms recent literature that has identified that swarms of large salps frequently occur in the Tasman Sea (Henschke et al., 2013), and this is likely the case in oceans around the world. Large salps have recently been found to be nutritionally important for several marine organisms and salp faecal pellets and carcasses play a large role in carbon export (Henschke et al., 2013). As salp remains are rarely found in sediment traps (Rowe and Staresinic, 1979), this suggests the

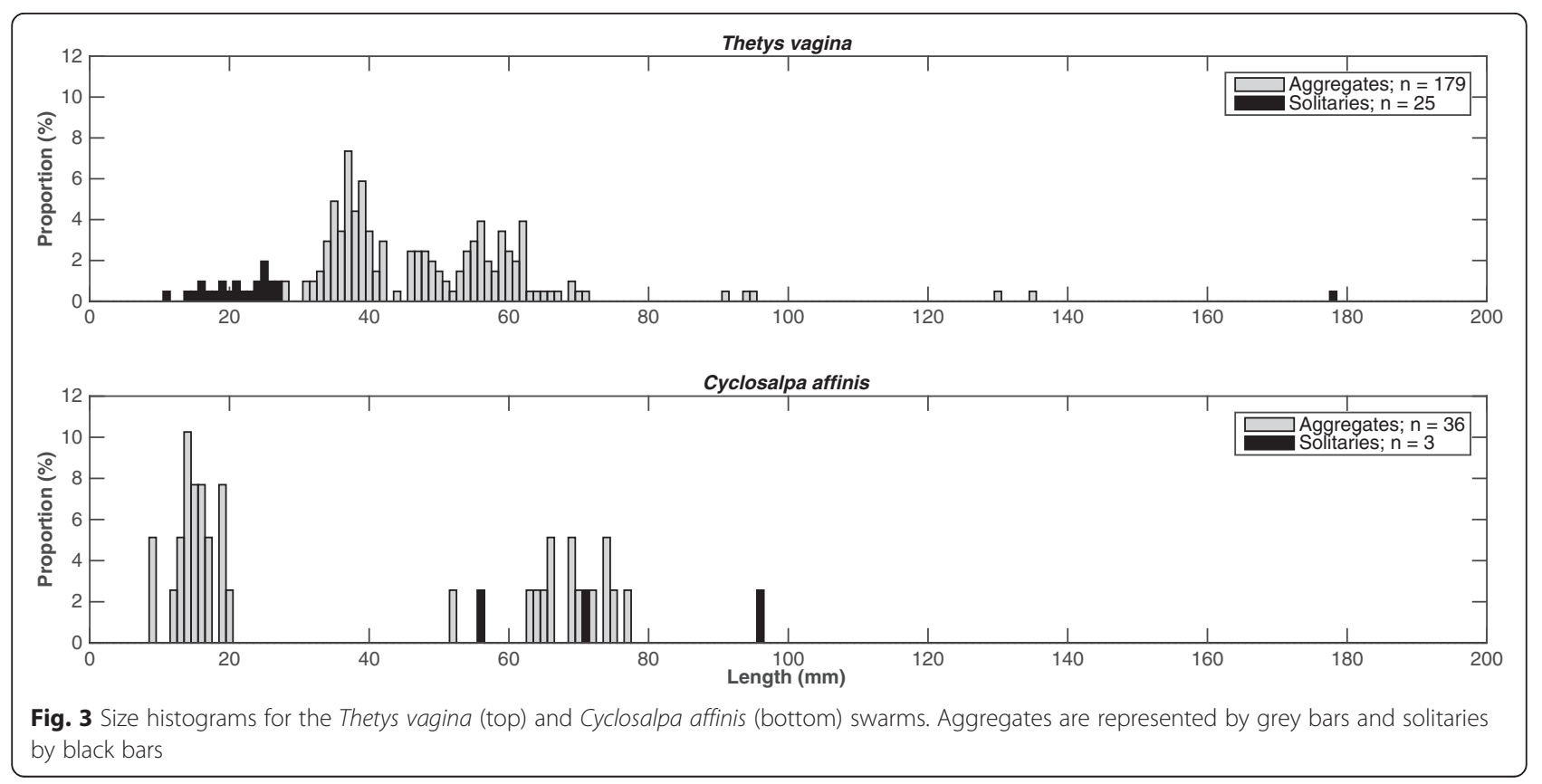


biogeochemical carbon budgets of the area are significantly underestimated. To incorporate salps into ecosystem models, it is important to understand which environmental factors promote high abundances of large salps in order to have accurate representations of their abundance and distribution. Their ephemeral nature will continue to make sampling of large oceanic salps difficult, but improved reporting of all encountered salp blooms will allow their contribution to global biogeochemical cycles to be better estimated.

\section{Competing interests}

The authors declare that they have no competing interests.

\section{Authors' contributions}

$\mathrm{NH}$, JDE and IMS designed the study, analysed the data and wrote the manuscript. IMS collected the data. All authors read and approved the final manuscript.

\section{Acknowledgements}

This work as funded by a UNSW Evolution and Ecology Research Centre Skills Transfer Award. The authors thank the captain and crew of the RV Southern Surveyor T01/2009. This is manuscript 180 from the Sydney Institute of Marine Science.

\section{Author details}

${ }^{1}$ Evolution and Ecology Research Centre, University of New South Wales, Sydney, NSW 2052, Australia. ${ }^{2}$ Sydney Institute of Marine Science, Building 22, Chowder Bay Road, Mosman, NSW 2088, Australia. ${ }^{3}$ School of Biological, Earth and Environmental Sciences, University of New South Wales, Sydney, NSW 2052, Australia.

Received: 6 April 2016 Accepted: 12 April 2016

Published online: 01 June 2016

\section{References}

Alldredge AL, Madin LP. Pelagic tunicates: Unique herbivores in the marine plankton. Bioscience. 1982;32:655-63.

Boehlert GW, Genin A. A review of the effects of seamounts on biological processes. Geophysical Monographs. 1987;43:319-34.

Bruland KW, Silver MW. Sinking rates of fecal pellets from gelatinous zooplankton (Salps, Pteropods, Doliolids). Mar Biol. 1981;63:295-300.

Fischer G, Futterer D, Gersonde R, Honjo S, Ostermann D, Wefer G. Seasonal variability of particle flux in the Weddell Sea and its relation to ice cover. Nature. 1988:335:426-8.

Henschke N, Bowden DA, Everett JD, Holmes SP, Kloser RJ, Lee RW, Suthers IM. Salp-falls in the Tasman Sea: a major food input to deep sea benthos. Mar Ecol Prog Ser. 2013;491:165-75.

Henschke N, Everett JD, Baird ME, Taylor MD, Suthers IM. Distribution of life history stages of the salp Thalia democratica in shelf waters during a spring bloom. Mar Ecol Prog Ser. 2011;430:49-62.

Henschke N, Everett JD, Doblin MA, Pitt KA, Richardson AJ, Suthers IM. Demography and interannual variability of salp swarms (Thalia democratica). Mar Biol. 2014;161:149-63.

Henschke N, Smith JA, Everett JD, Suthers IM. Population drivers of a Thalia democratica swarm: insights from population modelling. J Plankton Res. 2015. doi:10.1093/plankt/fbv024.

Heron AC. Population ecology of a colonizing species - pelagic tunicate Thalia democratica. 1. Individual growth-rate and generation time. Oecologia. 1972a;10:269-93.

Heron AC. Population ecology of a colonizing species - pelagic tunicate Thalia democratica. 2. Population growth-rate. Oecologia. 1972b;10:294-312.

Iguchi N, Kidokoro H. Horizontal distribution of Thetys vagina Tilesius (Tunicata, Thaliacea) in the Japan Sea during spring 2004. J Plankton Res. 2006;28:537-41.

Kawahata H, Ohta $\mathrm{H}$. Sinking and suspended particles in the South-west Pacific. Mar Freshwat Res. 2000;51:113-26.

Lavaniegos BE, Ohman MD. Long-term changes in pelagic tunicates of the California Current. Deep Sea Res Part II. 2003;50:2473-98.
Lebrato M, Pahlow M, Oschlies A, Pitt KA, Jones DOB, Molinero JC, Condon RH. Depth attenuation of organic matter export associated with jelly falls. Limnol Oceanogr. 2011;56:1917-28.

Lebrato $M$, de Jesus Mendes P, Steinberg DK, Cartes JE, Jones BM, Birsa LB, Benavides R, Oschlies A. Jelly biomass sinking speed reveals a fast carbon export mechanism. Limnol Oceanogr. 2013;58:1113-22.

Madin LP. Field observations on the feeding behavior of salps (Tunicata: Thaliacea). Mar Biol. 1974;25:143-7.

Madin LP, Deibel D. Feeding and energetics of Thaliaceans. In: Bone Q, editor. The Biology of Pelagic Tunicates. New York: Oxford University Press; 1998. p. 43-64.

Madin LP, Cetta CM, McAlister VL. Elemental and Biochemical Composition of Salps (Tunicata: Thaliacea). Mar Biol. 1981;63:217-26.

Madin LP, Kremer P, Hacker S. Distribution and vertical migration of salps (Tunicata, Thaliacea) near Bermuda. J Plankton Res. 1996;18:747-55.

McAlice BJ. Occurence of Thetys vagina Tilesius (Tunicata, Thaliacean) on the coast of Maine. Bull Mar Sci. 1986;39:717-8.

Nakamura EL, Yount JL. An unusually large salp. Pac Sci. 1958;12:181.

Quilty PG. Tasmantid and Lord Howe seamounts: biostratigraphy and palaeoceanographic significance. Alcheringa: An Australasian Journal of Palaenotology. 1993;17:27-53.

Rowe GT, Staresinic N. Sources of organic matter to the deep-sea benthos. Ambio Special Report. 1979;6:19-23.

Sims DW. A rare record of the salp, Thetys vagina (Tunicata: Thaliacean) from western Scottish waters. J Mar Biol Assoc UK. 1996;76:833-4.

Smith Jr KL, Sherman AD, Huffard CL, McGill PR, Henthorn R, Von Thun S, Ruhl HA, Kahru M, Ohman MD. Large salp bloom export from the upper ocean and benthic community response in the abyssal northeast Pacific: Day to week resolution. Limnol Oceanogr. 2014;59:745-57.

Stone JP, Steinberg DK. Long-term time-series study of salp population dynamics in the Sargasso Sea. Mar Ecol Prog Ser. 2014;510:111-27.

Sutherland KR, Madin LP, Stocker R. Filtration of submicrometer particles by pelagic tunicates. Proc Natl Acad Sci U S A. 2010;107:15129-34.

Suthers IM. Spatial variability of recent otolith growth and RNA indices in pelagic juvenile Diaphus kapalae (Myctophidae): an effect of flow disturbance near an island? Mar Freshwat Res. 1996;47:273-82.

Thompson H. Pelagic tunicates of Australia. Melbourne: Commonwealth Council for Scientific and Industrial Research; 1948.

Tsukamoto K, Yamada A, Okamura T, Kaneko H, Tanaka M, Miller J, Horie N, Mikawa N, Utoh T, Tanaka S. Positive buoyancy in eel leptocephali: An adaptation for life in the ocean surface layer. Mar Biol. 2009;156:835-46.

Vargas CA, Madin LP. Zooplankton feeding ecology: clearance and ingestion rates of the salps Thalia democratica, Cyclosalpa affinis and Salpa cylindrica on naturally occurring particles in the Mid-Atlantic Bight. J Plankton Res. 2004;26: 827-33.

Wood RA. Structure and seismic stratigraphy of the western Challenger Plateau. N Z J Geol Geophys. 1991;34:1-9.

Submit your next manuscript to BioMed Central and we will help you at every step:

- We accept pre-submission inquiries

- Our selector tool helps you to find the most relevant journal

- We provide round the clock customer support

- Convenient online submission

- Thorough peer review

- Inclusion in PubMed and all major indexing services

- Maximum visibility for your research

Submit your manuscript at www.biomedcentral.com/submit 